С.В. Мартиненко, В.А. Подоляк, В.О. Стеченко, М.С. Дияк

Харківський начіональний університет Повітряних Сил ім. І. Кожедуба, Харків

\title{
ДОСЛІДЖЕННЯ ЕЛЕМЕНТІВ МЕТОДИКИ РОЗПОДІЛУ ТА ПЕРЕКЛЮЧЕННЯ УВАГИ АВІАЦІЙНОГО ПЕРСОНАЛУ, ЯКИЙ ЗДІЙСНЮЄ ОПЕРАЦІЇ 3 ОРГАНІЗАЦІЇ ТА ОБСЛУГОВУВАННЯ ПОВІТРЯНОГО РУХУ
}

В статті поставлена і вирішена задача раціоналізації порядку розподілу та переключення уваги авіаційного персоналу, якій здійснює операції з організації та обслуговування повітряного руху. Це завдання $є$ складовою частиною безпекової компоненти авіаційної системи. Враховуючи важливість впливу людського чинника на безпеку польотів під час управління повітряним рухом та особливу роль процесів прийняття рішень у професійній діяльності визначеного авіаційного персоналу, розроблено відповідну методику, яка враховує фактори невизначеності, когнітивної складності, дефіџуиту часу та стресу у процесі оцінки повітряної обстановки.

Ключові слова: порядок розподілу та переключення уваги, повітряний простір, зони відповідальності, контрольні точки, оператор.

\section{Вступ}

Постановка проблеми. У результаті науковотехнічного прогресу за останні роки технічні засоби управління повітряним рухом та обладнання відповідних робочих місць авіаційного персоналу зазнали значних конструктивних змін. Це визначає протиріччя між науково-технічним прогресом і відставанням у методиці підготовки авіаційних фахівців для надійної експлуатації сучасної техніки. Але проблема професійної надійності в системі підготовки авіаційних фахівців ще далека від свого рішення, тому вона вимагає нових підходів, форм та методів. Це підтверджується великою кількістю аварій і катастроф, зумовлених людським фактором, на частку якого приходиться до 90\% загальної кількості авіаційних подій [2]. Тому підвищення безпеки польотів неможливо без підвищення рівня професійної підготовки авіаційних фахівців.

Для надійності професійної діяльності авіаційний персонал повинний мати комплекс якостей: увагу, мислення, оперативну пам'ять, стійкість до гіпоксії перевантаженням, вестибулярну стійкість і просторове орієнтування [3].

Як свідчить досвід, основною причиною помилок під час управління повітряним рухом $\epsilon$, насамперед, психологічні фактори: неправильна оцінка обстановки, порушення порядку розподілу та переключення уваги, тощо [5]. Ці чинники зазвичай називають “людською помилкою”.

Розподіл уваги з урахуванням особистісної складової об'єкта керівництва вивільняє активний час авіаційному персоналу (далі операторам), який здійснює операції з організації та обслуговування повітряного руху для роботи з іншими джерелами інформації та аналізу повітряної обстановки в цілому. Тому розробка раціональної методики розподілу і переключення уваги під час управління повітряним рухом набуває важливого значення.

Проблема раціонального розподілу та переключення уваги стосується не тільки стандартних процедур під час організації та обслуговування повітряного руху. Вона стосується діяльності авіаційного персоналу під час виникнення позаштатних (аварійних) ситуацій, а також діяльності з організації пошуку і рятування екіпажів, що зазнали (зазнають) лиха, надання своєчасної допомоги потерпілим внаслідок авіаційної події.

Аналіз останніх досліджень і публікацій. Opганізація повітряного руху в сучасних умовах $\epsilon$ складним завданням, пов'язаним 3 урахуванням людських та організаційних чинників, і спрямована на мінімізацію виникнення авіаційних подій та інцидентів [1].

За останні роки проблематиці впливу людського чинника на безпеку польотів під час управління повітряним рухом приділялось багато уваги.

Так роботи $[2 ; 5]$ присвячені розробці інформаційно-функціональної моделі надійності оператора аеронавігаційної системи з урахуванням особливостей його функціонування.

У роботі [3] розглядаються основні принципи розподілу та переключення уваги льотчиком при виконанні польотів за приладами.

У роботі [7] розглядаються питання зіставлення різних підходів до аналізу функціонування розподілу уваги.

У роботах [4-6; 8-12] розглядаються питання діагностики, прогнозування і керування рівнем безпеки польотів, психологічні аспекти прийняття рішень та особливості роботи авіаційного персоналу, який здійснює операції з організації та обслуговування повітряного руху. 
Але недостатня наукова розробленість методики розподілу та переключення уваги авіаційним персоналом, який здійснює операції з організації та обслуговування повітряного руху і те істотне значення, яке вона набуває для безпеки польотів в цілому, визначають актуальність теми дослідження.

Мета статті - дослідити окремі елементи методики розподілу та переключення уваги авіаційного персоналу, який здійснює операції з організації та обслуговування повітряного руху. Надати практичні рекомендації щодо побудови раціональної схеми розподілу та переключення уваги для Підвищення надійності роботи авіаційного персоналу.

\section{Виклад основного матеріалу}

На даний час закрита значна частина повітряного простору України над тимчасово окупованою територією Криму, враховуючи територіальні води, зону проведення операції об'єднаних сил (ООС), включаючи буферну зону. Також існує тиск з боку авіакомпаній, які перебувають під сильними конкурентними комерційними обмеженнями, необхідними для оптимізації маршрутів і координації. Ці питання призводять до складності і нестачі часу на операції з організації повітряного руху (ОрПР), що згодом може призвести до помилок операторів [1].

Для того щоб говорити про розподіл та переключення уваги, необхідно визначитися 3 термінами.

Усвідомлення середовища має вибірковий характер. Це явище не випадкове, а закономірне, тому що людина усвідомлює ті об'єкти, до яких вона уважна. Відображуваюча діяльність мозку людини організована таким чином, що вона буває спрямована на певні об'єкти, на них зосереджується, внаслідок чого підвищується їі ефективність.

Увага - спрямованість психічної діяльності людини та іiі зосередженість у певний момент на об'єкти або явища, які мають для людини певне значення при одночасному абстрагуванні від інших, в результаті чого вони відображаються повніше, чіткіше, глибше ніж інші [3].

Здатність до переключення уваги - навмисне іiі переведення з одного об'єкта на інший, з одного виду діяльності на інший. Можна говорити про повне й неповне переключення. У першому випадку попередня діяльність не гальмує ту, на яку була переключена увага, у другому - така інтерференція присутня [7].

Розподіл уваги полягає в здатності розосередити увагу на значному просторі, паралельно виконувати кілька видів діяльності або робити кілька різних дій. Розподіл уваги залежить від психологічного й фізіологічного стану людини. У разі стомлення, під час виконання складних видів діяльності, які вимагають підвищеної концентрації уваги, область розподілу звичайно звужується.

Обсяг уваги - це така їі характеристика, яка визначається кількістю інформації, здатною одночасно зберігатись у сфері підвищеної уваги (свідомості) людини. Кількісна характеристика середнього обсягу уваги людей: $7 \pm 2$ слова за один погляд (200 мс) - доросла людина здатна утримати стільки одиниць інформації [7]. Ця характеристика пов'язана 3 обсягом короткочасного запам'ятовування (рис. 1).

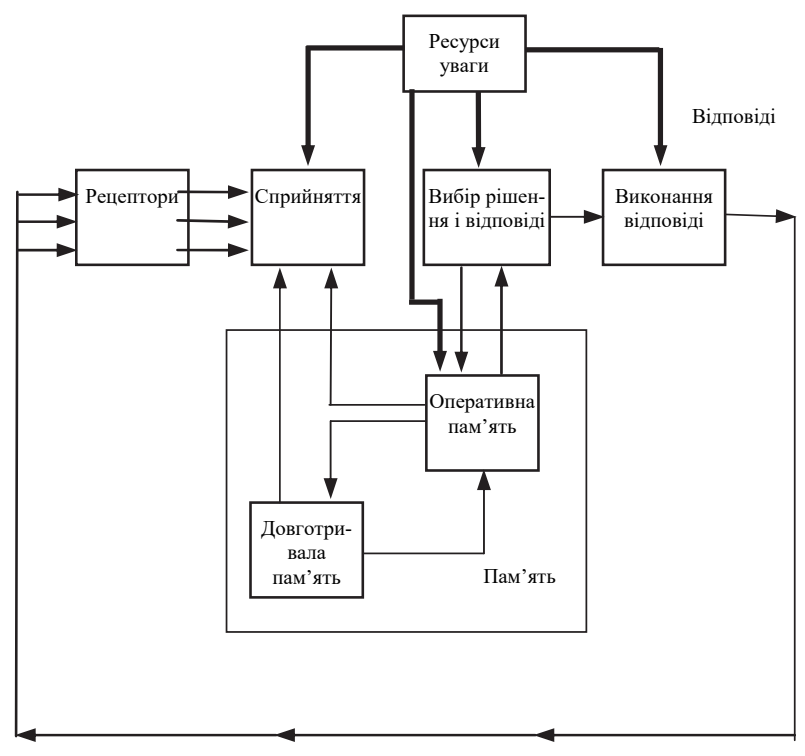

Рис. 1. Модель обробки інформації людиною Джерело: [2, с. 35].

Оператор часто опиняється перед необхідністю виявляти неузгодженість між заданою програмою виконання польотів і реальним станом на об'єкті, який знаходиться під управлінням, осмислювати проблемну ситуацію, ставити перед собою конкретне завдання щодо усунення неузгодженості і шукати шляхи іiі вирішення протягом обмеженого відрізка часу. Успішність діяльності оператора забезпечує оперативне мислення, що володіє рядом ознак:

- наявністю тісного зв'язку між сприйняттям і осмисленням швидкоплинної інформації;

- протіканням в жорстко лімітованих нормах часу;

- усвідомленням відповідальності за прийняте рішення;

- уявним формуванням образу повітряної обстановки, зіставленням образу заданої повітряної обстановки з образом ситуації, яка реально складається в повітрі;

- згорнутістю розумових дій, збільшенням в умовах дефіциту інформації та часу ролі інтуїції, а в окремих ситуаціях управлінням на рефлекторному рівні.

У процесі керівництва польотами можуть виникати різні за складністю ситуації, які вимагають від оператора максимальної активізації мислення 3 
врахування можливостей льотчика.

Надійність оператора може бути визначена як кількісними, так и якісними параметрами. До кількісних параметрів надійності оператора (і надійності техніки), відносяться: ймовірність безпомилкової роботи, частота помилок, інтенсивність помилок, тощо. Проаналізувати надійність оператора можна, застосовуючи показники надійності та формули для їх розрахунків (табл. 1).

Таблиця 1

Аналітичні залежності для показників надійності людини-оператора

\begin{tabular}{|c|c|c|}
\hline $\begin{array}{l}\text { Показники } \\
\text { надійності }\end{array}$ & $\begin{array}{c}\text { Формули для } \\
\text { розрахунків } \\
\text { показників } \\
\text { надійності }\end{array}$ & $\begin{array}{l}\text { Складові } \\
\text { формули }\end{array}$ \\
\hline $\begin{array}{l}\text { Імовірність } \\
\text { правильного } \\
\text { рімення опе- } \\
\text { раторської } \\
\text { задачі } P_{n p}\end{array}$ & $P_{n p}=1-\frac{m_{O T}}{N}$ & $\begin{array}{c}m_{O T} \text { та } N- \\
\text { відповідно } \\
\text { кількість } \\
\text { помилкових рішень і } \\
\text { загальна } \\
\text { кількість } \\
\text { розв’язуваних } \\
\text { завдань }\end{array}$ \\
\hline $\begin{array}{c}\text { Точність } \\
\text { розподілу } \\
\text { уваги } \\
\text { оператора } \gamma\end{array}$ & $\gamma=I_{i}-I_{o n}$ & $\begin{array}{c}I_{i} \text { - істинне або } \\
\text { номінальне } \\
\text { значення } \\
\text { параметра; } \\
I_{\text {on }} \text { - фактично } \\
\text { вимірюване або } \\
\text { регульоване } \\
\text { оператором значення } \\
\text { цього параметра }\end{array}$ \\
\hline
\end{tabular}

Джерело: розроблено авторами за даними [2, С. 49].

Під помилкою оператора будемо розуміти неправильне виконання або невиконання ним вказаних дій, що веде до появи аварійної ситуації або до створення такої ситуації, яка може призвести до аварійного ефекту.

Вичерпною характеристикою будь-якої випадкової величини, наприклад, помилки оператора, при тривалості $t$ безпомилкової, $\epsilon$ функція розподілу $F(t)$, яку назвемо моделлю розподілу помилок опеpaтора.

Вона пов'язана 3 ймовірністю помилки $Q(t)$ тотожністю, яка випливає з визначення функції розподілу:

$$
F(t) \equiv Q(t) .
$$

Модель помилок, описана функцією розподілу $F(t)$, пов'язана з імовірністю безпомилкової роботи оператора $R(t)$, яку назвемо моделлю надійності оператора, що визначається співвідношенням виду:

$$
R(t)=1-Q(t) .
$$

Крім того, помилки оператора можливо класифікувати за місцем у структурі діяльності (рис. 2) та за наслідками (рис. 3).

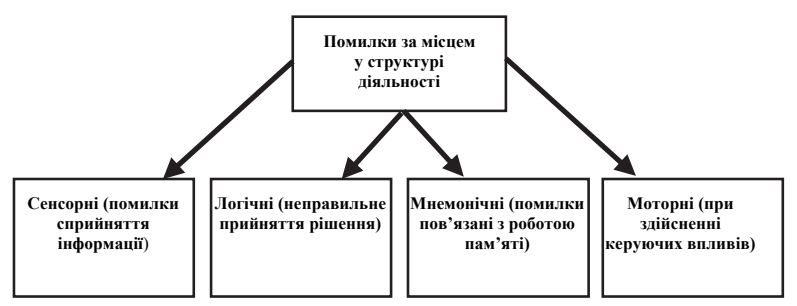

Рис. 2. Помилки оператора за місцем у структурі діяльності

Джерело: [5, С. 71].

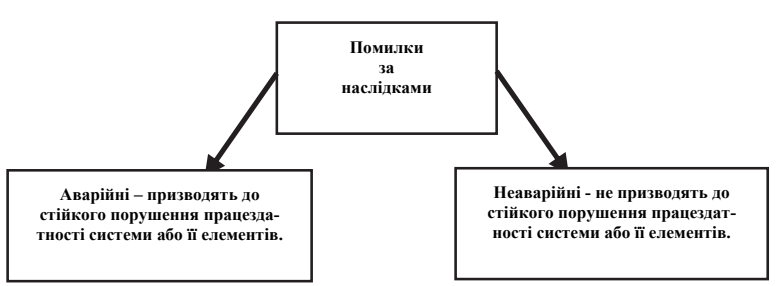

Рис. 3. Класифікація помилок оператора за наслідками

Джерело: [5, С. 72].

Отже, модель надійності оператора можна визначити як математичну модель, яка встановлює зв'язок між показниками надійності оператора, характеристиками надійності елементів авіаційної системи і параметрами процесу іï функціонування.

Однак не всі моделі помилок, що застосовуються в теорії надійності можна використовувати для розрахунків ергатичних систем. Багато 3 них мають ряд недоліків, неприйнятних для використання у даних системах.

Оператор являє собою значно складнішу систему, ніж будь-яка машина, яка працює або буде розроблена в майбутньому. На даний час замінити людину-оператора не може жодна машина, навіть за умови, що вона здатна повністю продублювати роботу органів чуття і вищу нервову діяльність людини, наприклад сприйняття, впізнання й прийняття рішень.

Оператору внутрішньо властива менша стабільність у порівнянні з машиною. На нього впливає значно більша кількість факторів. Робота оператора залежить від його фізіологічного стану, ступеня втоми, впливів оточуючих подразників (наприклад, шуму), тривалості навчання, спонукальних мотивів, стимулювання та інших факторів.

Однак дії оператора можна оцінити так само, як функціонування апаратури - шляхом викорис- 
тання вхідних і вихідних параметрів. Це дозволяє будувати алгоритми та створювати моделі для опису дій людини-оператора під час виконання обов'язків на робочому місці, враховуючі порядок розподілу та переключення уваги і використовувати ці моделі під час навчання авіаційного персоналу, якій здійснює операції з організації та обслуговування повітряного руху, а також в їх практичній діяльності.

При створені моделі необхідно враховувати те, щоб вищезазначена модель була гнучкою й була здатна використовуватися та інтегруватися до структури надійності авіаційної системи.

Добре натренований оператор здатний виконати за 1 хвилину 120-130 переміщень погляду 3 об'єкту на об'єкт [3]. Це дозволяє йому сприйняти необхідну для управління інформацію навіть при нераціональному порядку розподілу уваги. Але при ускладненні повітряної або наземної обстановки оператор, який не вміє економно використовувати свою увагу, може опинитися в ситуації, коли він буде нездатний впоратися з навантаженням. Наприклад, якщо керівник ближньої зони буде витрачати всю свою увагу на формування потоку повітряних суден в точці виконання розвороту на посадковий курс, то може втратити контроль за іншими повітряними суднами, які можуть наближатись до першого розвороту, до рубежу передачі управління в дальню зону, відхилятись від лінії заданого шляху на маршруті або за межі пілотажної зони, тощо.

Оператор, навчений раціональному розподілу та переключенню уваги, буде витрачати на конкретну точку тільки певну частину тієї уваги, яку він має, а частину уваги, яка залишилась (резерв), зможе використати при ускладнені обстановки.

Варіантів переключення уваги між об'єктами можна придумати безліч. Але, як що ці схеми виявляться “жорсткими”, вони не будуть раціональними, тому що складно врахувати всі фактори, які визначають дії оператора в такому динамічному і складному процесі, як управління повітряним рухом.

Який порядок розподілу та перемикання уваги можна вважати раціональним? Можливо такий, який забезпечить своєчасне отримання інформації для якісного і надійного (безпомилкового) управління повітряним рухом при мінімальній витраті уваги.

Щоб відпрацювати раціональну методику розподілу та переключення уваги між об'єктами, необхідно визначити точки контролю за повітряними суднами в повітряному просторі зони відповідальності конкретного оператора з урахуванням їх пріоритетності. Крім того, необхідно відпрацювати методику ведення, так званого, процедурного контролю - заповнення відповідного бланку, на якому оператор відображає позивний командира екіпажу, місце його знаходження в повітряному просторі та етап польоту за допомогою умовних позначок.

Точки контролю за повітряними суднами в повітряному просторі зони відповідальності оператора 3 урахуванням їх пріоритетності, які можуть бути застосовані для побудови схеми розподілу та переключення уваги:

1. Точки схем набору висоти, польотів.

2. Точки схем зниження й заходу на посадку.

3. Характерні точки пілотажних зон і зон очікування.

4. Точки зміни напрямку польоту.

5. Точки перетинання (входу та виходу) маршрутів ОПР.

6. Точки проходу характерних орієнтирів, що упізнаються візуально або за допомогою бортових радіо- та радіолокаційних засобів.

7. Точки початку набору висоти або зниження (зміни ешелонів) у коридорах або зонах з установленими режимами польотів.

8. Точки перетинання меж районів (зон) відповідальності взаємодіючих пунктів управління.

Таким чином, оператор постійно прослуховує радіообмін, розподіляе увагу між контрольними точками та веденням процедурного контролю, а також переключає увагу між контрольними точками. Визначивши пріоритети, можна побудувати найбільш раціональну схему розподілу та переключення уваги (рис. 4).

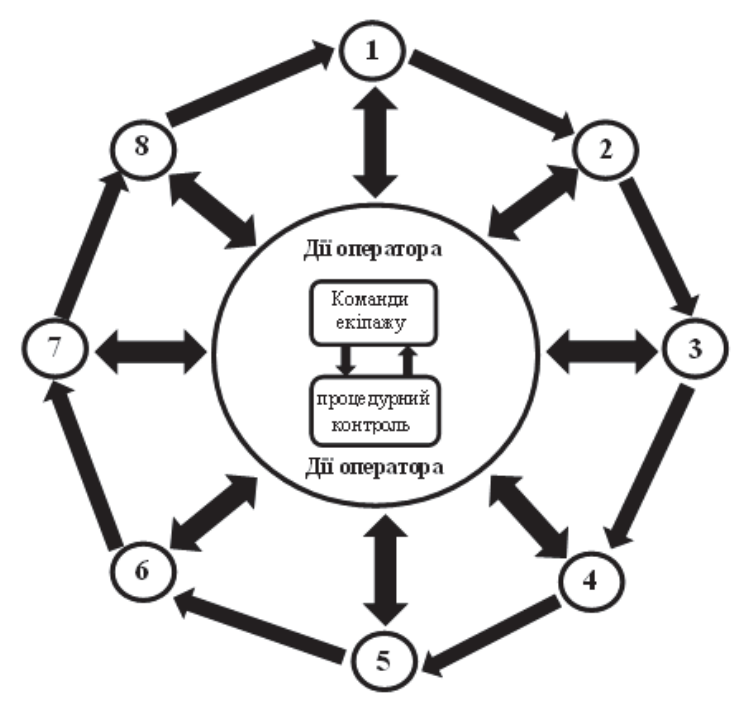

Рис. 4. Варіант схеми розподілу та переключення уваги

Джерело: розроблено авторами.

При цьому деякі точки на схемі, залежно від повітряної обстановки, можуть бути виключені. Деякі, навпаки, при ускладненні обстановки та збільшенні навантаження потребуватимуть більше уваги, а тому можуть повторюватись на схемі з потрібною періодичністю. 
Порядок розподілу та переключення уваги залежить від виконуваних завдань, особливостей зони відповідальності, завантаження планової таблиці польотів, метеорологічних умов, загальної повітряної обстановки, тощо. При виникненні особливих випадків у польоті та аварійних ситуацій порядок розподілу та переключення уваги, також суттєво зміниться.

Можливості операторів 3 розподілу та переключення уваги враховуються для розробки послідовності відпрацювання вправ курсів підготовки авіаційного персоналу. Ці можливості також враховуються для розробки додаткових вимог, які висуваються під час проведення випробувань для присвоєння (підтвердження) класної кваліфікації [13] Залежно від досвіду роботи, вмінь та навичок оператор повинен працювати 3 навантаженням, яке не перевищує вимоги відповідно до його класної кваліфікації.

Перевищення встановленого навантаження може призвести до виникнення помилок, інцидентів та авіаційних подій.

Вміння вирішувати складні, комплексні завдання з управління повітряним рухом може бути досягнуто раціоналізацією порядку розподілу та переключення уваги, а також постійним тренуванням на тренажерному обладнанні в рішенні таких завдань. Такі тренування операторів повинні максимально наповнюватися додатковими завданнями, що ускладнюватимуть управління повітряним рухом.

Важливо, щоб оператор був здатний самостійно та свідомо виконувати дії з розподілу та переключення уваги, під час управління повітряним рухом, засновуючись на оцінці обстановки, яка постійно змінюється.

\section{Висновки}

Досліджені окремі елементи методики розподілу та переключення уваги. Надані практичні рекомендації щодо побудови раціональної схеми розподілу та переключення уваги, які дозволяють підвищити надійність роботи з організації та обслуговування повітряного руху. Подальші дослідження будуть спрямовані на розробку математичної моделі розподілу та переключення уваги операторами на конкретних робочих місцях авіаційного персоналу, який здійснює операції з організації та обслуговування повітряного pyxy.

\section{Список літератури}

1. ДСТУ 3433-96. Надійність техніки. Моделі відмов. Основні положення. - К., 1996. -42 с.

2. Кожохіна О.В. Модель надійності оператора аеронавігаційної системи / О.В. Кожохіна, В.М. Грібов, С.І. Рудас // Електроніка та системи управління. - 2014. - № 4(42). - С. 128-135.

3. Качоровский И.Б. Распределение и переключение внимания при полётах по приборам / И.Б. Качоровский. М.: Воениздат, 1972. - 104 с.

4. Кожохіна О.В. Оцінка надійності роботи операторів ОрПР / О.В. Кожохіна, С.В. Ходзицька, І.С. Порхун // Збірник тез доповідей науково-технічної конференції “Проблеми розвитку глобальної системи зв'язку, навігації, спостереження та організації повітряного руху CNS/ATM”. - Київ, 19-21 вересня 2012 р. - С. 108.

5. Рева О.М. Чинники прийняття рішень авіадиспетчером у процесі керування повітряним рухом / О.М. Рева, С.О. Дмитрієв, Г.М. Селезньов // Вісник Національного Авіаційного Університету. - 2009. - № 1. - С. 13-19.

6. Жорник О.Є. Статевовікові особливості розподілу і переключання уваги у сенсомоторних задачах різного рівня складності і змісту / О.Є. Жорник, Є.В. Заїка // Вісник Харківського національного університету ім. В.Н. Каразіна. 2008. - № 807. - C. 131-135.

7. Пилипенок О.Н. Особенности моделирования условий функционирования диспетчера Tower / О.Н. Пилипенок // Матеріали XXXII Всеукраїнської науково-практичної конференції молодих учених та курсантів “Авіація та космонавтика: стан, досягнення і перспективи”. - Кіровоград, 12 квітня 2012 р. - С. 19-21.

8. Курлін В.І. Інформаційні пастки - основа формування складних аварійних ситуацій / B.I. Курлін // Матеріали VII науково-практичної конференції. - Київ, 28-29 березня 2012p. - С. 12-14.

9. Фрайнман I.М. Критерії готовності майбутніх авіадиспетчерів допрофесійної самореалізації / І.М. Фрайнман // Наукові записки. - 2009. - № 97. - С. 310.

10. Антистрессовая подготовка пилотов и авиадиспетчеров / А.В. Скрипец, Ю.В. Грищенко, А.Е. Волков, Д.А. Волошенюк, Е.М. Хохлов // Кибернетика и вычислительная техника. - 2011. - № 163. - С. 54-64.

11. Харченко В.П. Інтеграція засобів діагностики, прогнозування і керування рівнем безпеки польотів / В.П. Харченко, О.Є. Луппо, О.М. Алєксєєв // Вісник Національного Авіаційного Університету. - 2007. - № 2. - С. 43-49

12. Наказ Міністерства оборони України "Про порядок підготовки осіб групи керівництва польотами державної авіації України № 367 від 28.07.2015” [Електронний ресурс]. - Режим доступу: https://zakon.rada.gov.ua/laws/show/z0972-15. 
Bidомості про авторів:

Мартиненко Сергій Вікторович

старший викладач кафедри

Харківського національного університету

Повітряних Сил ім. І. Кожедуба,

Харків, Україна

https://orcid.org/0000-0001-9199-5776

Подоляк Владислав Андрійович курсант

Харківського національного університету

Повітряних Сил ім. І. Кожедуба,

Харків, Україна

https://orcid.org/0000-0003-2788-4910

Стеченко Владислав Олександрович курсант

Харківського національного університету

Повітряних Сил ім. І. Кожедуба,

Харків, Україна

https://orcid.org/0000-0003-4701-6280

\section{Дияк Михайло Сергійович}

курсант

Харківського національного університету

Повітряних Сил ім. І. Кожедуба,

Харків, Україна

https://orcid.org/0000-0003-1999-0641
Information about the authors:

\author{
Sergey Martynenko \\ Senior Instructor \\ of Department of Ivan Kozhedub \\ Kharkiv National Air Force University, \\ Kharkiv, Ukraine \\ https://orcid.org/ 0000-0001-9199-5776 \\ Vladislav Podolyak \\ Cadet \\ of Ivan Kozhedub Kharkiv \\ National Air Force University, \\ Kharkiv, Ukraine \\ https://orcid.org/0000-0003-2788-4910 \\ Vladislav Stechenko \\ Cadet \\ of Ivan Kozhedub Kharkiv \\ National Air Force University, \\ Kharkiv, Ukraine \\ https://orcid.org/0000-0003-4701-6280 \\ Mykhailo Dyak \\ Cadet \\ of Ivan Kozhedub Kharkiv \\ National Air Force University, \\ Kharkiv, Ukraine \\ https://orcid.org/0000-0003-1999-0641
}

\section{ИССЛЕДОВАНИЕ ЭЛЕМЕНТОВ МЕТОДИКИ РАСПРЕДЕЛЕНИЯ И ПЕРЕКЛЮЧЕНИЯ ВНИМАНИЯ АВИАЦИОННОГО ПЕРСОНАЛА, КОТОРЫЙ ОСУЩЕСТВЛЯЕТ ОПЕРАЦИИ ПО ОРГАНИЗАЦИИ И ОБСЛУЖИВАНИЮ ВОЗДУШНОГО ДВИЖЕНИЯ}

С.В. Мартыненко, В.А. Подоляк, В.А. Стеченко, М.С. Дияк

В статье поставлена и решена задача оптимизачии порядка распределения и переключения внимания авиачионного персонала, который осуществляет операщии по организащии и обслуживанию воздушного движения. Эта задача является составляющей компонентой безопасности авиационной системы. Учитывая важность влияния человеческого фактора на безопасность полетов при управлении воздушным движением и особую роль процессов принятия решений в профессиональной деятельности такого авиачионного персонала, разработана соответствующая методика, которая учитывает факторы неопределенности, когнитивной сложности, дефицита времени и стресса в процессе упорядочения воздушной обстановки.

Ключевые слова: порядок распределения и переключения внимания, воздушное пространство, зоны ответственности, контрольные точки, оператор.

\section{ELEMENTS RESEARCH OF METHODOLOGY OF ATTENTION SWITCHING AND DISTRIBUTION BY AVIATION PERSONNEL WHO CARRIES OUT ACTIONS OF AN AIR TRAFFIC CONTROL AND ORGANIZATION}

\section{S. Martynenko, V. Podolyak, V. Stechenko, M. Dyak}

The article set task and solves the problem of the aviation personnel attention switching and assignment optimization, who carries out operations of air traffic control and organization. This task is a part of the aviation system safeness. Considering to the importance of the human factor influence on flight safety during operation of an air traffic control and the special role of aviation personnel decision-making processes in the professional activities, special technique developed which consider uncertainty factors, cognitive complexity, time pressure and stress during the optimization process of the air situation. Operator actions rated also as hardware functioning with the help of using input and output parameters. This give a chance to find the algorithms and create models the description of the operator actions on the duty at workplace, taking into account attention switching and distribution of it. These models are advisable to use when training aviation personnel who carries out actions of an air traffic control and organization and in their practical activities. Attention distributing and switching methodology depends on the tasks that carried out also on the area of responsibility specialties also on the flights planned table, meteorological conditions, the air space in general and other factors. In occurrence of special cases in flight or emergency situations load on the distributing and switching of attention will also increase greatly. Due to the rational attention distribution and switching while performing standard procedures for air traffic control and organization, an attention reserve created. Aviation personnel can use this reserve in a cause of an special cases (emergency) situation as well as for organization of the search and rescue operations for the aircraft that in aviation accident, and providing rescue to the victims of an aviation accident in time. It is very important that operator can make actions of atention distribution and switching which are based on situation assessment that is changing all the time by himself and consciously while he controls air traffic.

Keywords: order of attention distribution and switching, airspace, responsibility areas, control points, operator. 